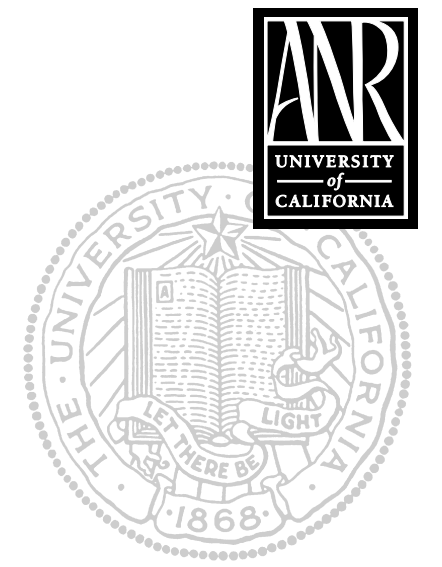

UNIVERSITY OF

CALIFORNIA

Division of Agriculture and Natural Resources

http://anrcatalog.ucdavis.edu

\title{
Vegetable Diseases Caused by Soilborne Pathogens
}

STEVEN T. KOIKE is Plant Pathology Advisor, University of California Cooperative Extension, M onterey County; KRISHNA V. SUBBARAO is Plant Pathology Specialist, Department of Plant Pathology, UC Davis; R. MICHAEL DAVIS is Plant Pathology Specialist, Department of Plant Pathology, UC Davis; and THOMAS A. TURINI is Plant Pathology Advisor, University of California Cooperative Extension, Imperial County.

Soilborne plant pathogens can significantly reduce yield and quality in vegetable crops. These pathogens are particularly challenging because they often survive in soil for many years and each vegetable crop may be susceptible to several species.

Simultaneous infections from multiple soilborne pathogens sometimes result in a disease complex that can further damage the crop. Many diseases caused by soilborne pathogens are difficult to predict, detect, and diagnose. In addition to this, the soil environment is extremely complex, making it a challenge to understand all aspects of diseases caused by soilborne pathogens.

Special terms are used when discussing soilborne pathogens. Pathogens are the biological agents that cause or incite the problem. Symptoms are the visible reactions (e.g., root decay, tissue discoloration, crown rot, wilting of foliage, etc.) of the plant when it is infected and colonized by the pathogen. The collective manifestation of symptoms caused by the pathogens is the disease. In contrast to a symptom, a sign is the visible evidence of the presence of the pathogen itself (e.g., mycelial growth, large sclerotia, bacterial ooze, or nematode cysts). Inoculum is the biological object (e.g., spore, mycelium, sclerotium, cells) that is able to infect the host and cause the disease. The term soilborne pathogens, therefore, can be defined as pathogens that cause plant diseases via inoculum that comes to the plant by way of the soil.

The most familiar diseases caused by soilborne pathogens are probably rots that affect belowground tissues (including seed decay, damping-off of seedlings, and root and crown rots) and vascular wilts initiated through root infections. A few soilborne pathogens, however, cause foliar diseases with symptoms and damage appearing on aboveground parts of plants. For example, the lettuce anthracnose pathogen survives in the soil in the form of tiny resting structures (microsclerotia). When raindrops splash pathogen-laden soil particles onto lettuce leaves, the fungus moves onto the plants and causes a leaf spot disease. Similarly, the soilborne pathogen Sclerotinia sclerotiorum survives in soil as sclerotia. Under certain environmental conditions, the sclerotia produce tiny mushroom-like structures (apothecia) that release aerial spores; these spores then land on susceptible foliage and cause a foliar disease.

Because soil ecology is so complex, it is also important that we define the ecological roles of soilborne pathogens. Soilborne pathogens can generally be divided into soil inhabitants (those able to survive in soil for a relatively long time) and soil invaders or soil transients (those only able to survive in soil for a relatively short time). Many soilborne plant pathogens also can function and live as non-pathogenic soil organisms under certain conditions. If these pathogens are in contact with dead and decaying plant tissues, they can grow and survive on these substrates and thus be seen as saprobes or saprophytes (organisms that live on decaying organic matter). 


\section{MAJOR PATHOGEN GROUPS}

The agents that cause soilborne diseases make up a diverse group. Fungi, which are multicellular microorganisms, cause most soilborne vegetable diseases and so are considered the most important pathogen group. Plant-pathogenic fungi fall into five main taxonomic classes based on morphological and biological characteristics:

Plasmodiophoromycetes, Zygomycetes, Oomycetes, Ascomycetes, and Basidiomycetes. Some species of Ascomycetes and Basidiomycetes form a second type of spore that is asexually produced. These asexual stages are placed in an additional, separate class, the Fungi Imperfecti. N otable Oomycetes pathogens include A phanomyces, Bremia, Phytophthora, and Pythium. Important Ascomycetes are M onosporascus and Sclerotinia. Examples of soilborne Fungi Imperfecti pathogens are Fusarium, Rhizoctonia, and Verticillium. Plasmodiophora brassicae (causal agent of clubroot disease of brassicas) and Spongospora subterranea (causal agent of powdery scab of potato) are the main soilborne Plasmodiophoromycetes pathogens. Many soilborne fungi persist in soil for long periods because these organisms produce resilient survival structures like melanized mycelium, chlamydospores, oospores, and sclerotia. The thin-walled mycelium typical of many fungi survives for only a short time in the soil.

Bacteria are single-celled organisms that have rigid cell walls but lack a membrane-bound nucleus. Fewer diseases are caused by soilborne bacterial pathogens than by fungal pathogens. Examples of such bacteria are Erwinia, Rhizomonas, and Streptomyces. Pathogens in the Pseudomonas and Xanthomonas groups usually persist in the soil for only a short time.

There are few soilborne viruses that affect vegetable crops. Viruses are subcellular entities composed of genetic material with a surrounding protein coat. Once the genetic material of a plant virus is inserted into a host cell, it causes the cells to manufacture more virus particles. Virus disease symptoms include stunting of the plant, tissue distortions, and discolorations of foliage and fruit. Soilborne viruses generally survive only in the living tissues of the host plant or in the nematode or fungal vectors that transmit them to the plant hosts. Lettuce big vein disease, for instance, is caused by the Mirafiori lettuce virus; the virus is present inside a primitive soil fungus (Olpidium brassicae) that moves in soil water, attaches itself to lettuce roots, and transmits the virus. Another example of a soilborne virus that affects vegetables is the lettuce necrotic stunt virus (LNSV). This is an unusual case in that LNSV has no known biological vector, but is found in river water and in soils contaminated by such water.

Nematodes are tiny, nonsegmented roundworms. Soilborne plant-parasitic nematodes spend most of their lives in the soil, either as external feeders on plant roots or as residents inside roots. Nematodes affect crops by reducing plant vigor and growth. In an affected field, some plants will be heavily infested and others will not, with the result that the overall crop will mature unevenly or the quality of the produce will be lower. In soil, plant parasitic nematodes either live freely or are present as eggs or durable cysts. Root knot nematodes (M eloidogyne species) cause a general reduction in vigor for many plant species and can cause severe distortions and swellings of roots, particularly affecting the marketability of root crops such as carrots. Cyst nematodes (Heterodera species) can survive in the soil for long periods because the mature body of the female cyst nematode dries in the form of a leathery cyst, protecting the eggs within. Needle nematodes (Longidorus africanus) feed on the growing points at the tips of the roots, causing root tips to swell and causing roots to fork or branch out. Stubby root nematodes (Paratrichodorus species) reduce the length of roots. 


\section{BIOLOGY OF SOILBORNE PATHOGENS}

Survival. A soilborne pathogen's ability to survive in soil depends in part on the biological group to which it belongs. Few bacterial pathogens are true, long-term soil inhabitants; most survive for limited periods as saprobes on plant debris or roots, or directly in the soil. These species' bacterial cells do not produce resilient endospores and the vegetative cells are not particularly resilient in adverse environments. Some species survive by secreting slimy material that dries to form protective layers around the cells, enabling them to withstand unfavorable conditions.

Fungal pathogens survive in soil as saprobes on host plant debris or on other types of organic matter present in soil, or as free-living organisms living directly in the soil. Many of these fungi produce resilient survival structures on organic materials; the structures are released into the soil by tillage operations and through decomposition of the infected material. Survival structures can withstand low or high temperature extremes, dry conditions, and periods when no suitable host is present. Environmental factors, however, may affect how long the survival structures remain viable. The sclerotia of some root-infecting pathogens can be sensitive to desiccation. Low soil temperatures can be detrimental to pathogens that are adapted to warmer conditions. Such conditions can limit the development of pathogens such as Macrophomina phaseolina on beans and Sclerotium rolfsii on various crops.

Distribution of pathogens in soil. The horizontal and vertical distribution of soilborne pathogens depends on production practices, cropping history, and a variety of other factors. Along a vertical axis, the inoculum of most root pathogens lies within the top 10 inches of the soil profile, the layers where host roots and tissues and other organic substrates are found. On the horizontal plane, distribution of inoculum in a field is usually aggregated in areas where a susceptible crop has been grown: survival structures produced in diseased tissues are likely to remain in the area where the affected hosts have grown.

Because tillage operations involve fragmenting, moving, and burying plant residues, tillage can result in the vertical and horizontal redistribution of pathogens. Pathogen propagules can be moved both deeper and shallower in the soil profile. Deeper-placed propagules can have adverse effects on the survival of these structures. On the other hand, exposure to heat, cold, and drying may kill pathogens that have been brought to the soil surface. On a horizontal scale, tillage redistributes inoculum that was at first present in just a few infested areas and spreads it throughout the field. Eventually, the inoculum produced after each susceptible crop could be spread to previously uninfested areas, contributing to increased disease on succeeding crops. The greatest concentration of nematodes usually occurs in the top 6 inches of soil, though nematodes have been recovered from as deep as 4 to 5 feet. Nematode distribution in fields is irregular and usually dictated by the presence of host roots and root exudates and the movement of soil.

Factors that influence infection. Many factors in the soil influence the activity of soilborne pathogens and diseases: soil type, texture, $\mathrm{pH}$, moisture, temperature, and nutrient levels are among them. Soil is a porous mixture of inorganic particles, organic matter, air, and water. Soil texture, which results from the size of mineral particles, and soil structure, which is the arrangement of soil particles into groups (aggregates), significantly influence the development of root disease. Well-aerated, welldrained soils create conditions that discourage root diseases. Soils that drain poorly, however, tend to favor the survival and distribution of soilborne pathogens such as Pythium, Phytophthora, and Aphanomyces. Fusarium and Verticillium wilts can also be more severe in wet soils than in dry soils. Only a few root diseases are favored by drier soils (for example, common scab of potato caused by Streptomyces scabies). 
Soil pH is another important factor influencing the development of certain soilborne diseases. A classic example is clubroot disease of crucifers caused by Plasmodiophora brassicae. Clubroot is a major problem in acidic soils (5.7 pH or lower). The disease is dramatically reduced when the $\mathrm{pH}$ rises from 5.7 to 6.2 and is virtually eliminated at soil $\mathrm{pH}$ values greater than 7.3 to 7.4. This disease, which once posed a major threat in the Salinas Valley, has been managed for decades by liming the soil to raise the $\mathrm{pH}$. Similarly, common scab of potatoes is favored by a pH of 5.2 to 8.0 but is reduced dramatically by soil pH values lower than 5.2 .

Soil temperature is generally a less critical factor for soilborne problems on vegetable crops. Colder soil temperatures usually slow pathogen development and reduce the severity of disease. Under warmer temperatures, pathogens grow and develop more rapidly and can cause more disease. Melon vine decline (caused by M onosporascus cannonballus) and sudden wilt (caused by Pythium aphanidermatum) are two cucurbit diseases that are favored by high temperatures.

Another factor that has a major influence on soilborne disease is plant nutrition. The effect of nitrogen has received the most extensive study. High levels of soil nitrogen increase the growth rates of crops, enhance the growth of tender, succulent plant tissue, and prolong the plants' vegetative phase. Plants in this condition may be more vulnerable to attack by some soilborne pathogens. Low levels of soil nitrogen weaken plants and also predispose them to attack by some pathogens.

The type of nitrogen fertilizer can also indirectly affect soil pH and thus have an effect on soilborne diseases. The positive charge on an ammonium ion allows it to be adsorbed by plant roots, resulting in the release of hydrogen ions into the surrounding soil. These additional hydrogen ions lower the soil's pH; consequently, diseases that are more common in acidic soils increase in severity when ammonium nitrogen fertilizer is applied.

In contrast, nitrates can favor other diseases by altering the virulence and growth of the pathogens and by increasing host susceptibility. These effects can be seen with the vascular wilt pathogens. Research indicates that an increase in nitrate levels can increase the severity of Verticillium wilt but reduce that of Fusarium wilt; however, higher ammonium levels can cause Fusarium wilt to be more severe. Other soil nutrients may also have an affect on soilborne diseases, but they have not been studied as extensively as nitrogen.

Ecology. Soilborne pathogens share the soil environment with many other organisms and compete with them for limited resources. In addition, many of the microorganisms in soil are directly or indirectly antagonistic to soilborne pathogens. Direct antagonism takes place when, because of the environmental niche it occupies in the soil environment, an organism excludes a pathogen from the soil, or when an organism parasitizes soilborne pathogens. With indirect antagonism, the microflora may release substances that are toxic to the pathogen. In some soils, called suppressive soils, antagonistic microflora suppress the activity and development of soilborne pathogens to such a great extent that they significantly reduce the instance of plant disease. Researchers are attempting to create suppressive soil conditions deliberately by introducing microorganisms into the soil or by incorporating certain crop residues that enhance microbial growth and diversity. An example of this research is the recent use of broccoli residue to enhance suppression of Verticillium dahliae and Sclerotinia minor pathogens. 


\section{DIAGNOSING SOILBORNE DISEASES}

Diagnosing a soilborne disease, in general, is not much different from diagnosing a disease that occurs on aboveground plant parts. Here are a few procedures that may prove useful:

- Prepare a list of known suspected soilborne pathogens. A particular crop being grown in a specific region generally is susceptible to a relatively short list of soilborne pathogens. By compiling this list ahead of time, you can narrow the group of pathogens to watch for (see Table).

- Carefully examine all parts of affected plants. Complete observation of roots, crowns, and other belowground plant parts is essential. You have to consider the symptoms that you observe aboveground together with the belowground symptoms in order to get a complete picture of a plant's condition.

- Watch for symptoms that occur in noticeable patterns, non-random distributions, or in association with physical features at the sites. For example, if symptomatic plants are associated with irrigation patterns or areas of excess water, that information can influence your diagnosis.

- Collect a representative sample for laboratory analysis. Plants must be carefully dug up so as to preserve roots and other belowground plant parts. The sample should consist of a sufficient number of diseased plants showing typical symptoms as well as a few healthy specimens for comparison. A qualified plant diagnostic laboratory can then confirm the actual cause of the soilborne disease.

- Keep a record of the soilborne diseases that you confirm at each site. This type of historic record can be especially useful later on because soilborne pathogens tend to persist for long periods of time. If you know which pathogens have been observed in a field, you can make better crop rotation decisions.

\section{SOILBORNE DISEASE CONTROL STRATEGIES}

Management of soilborne diseases depends on a thorough knowledge of the pathogen, the host plant, and the environmental conditions that favor infection. In order for a disease to develop, all three factors must be present. The pathogen (a virulent, infectious agent) must have viable inoculum, such as zoospores, available to infect the host. The host (a susceptible plant) must be exposed to the pathogen's inoculum, and be physiologically susceptible to infection. Finally, the environmental conditions must be favorable for the infection of the plant and growth of the pathogen. For example, the soil must be saturated with water for a certain period of time in order for water molds to develop and infect roots. An understanding of these pathogen-host-environment dynamics will help you devise a disease management strategy.

An effective disease management option must be economical: that is, the value of the crop saved must exceed the cost of control. For this reason, assessments of disease incidence, disease severity, and potential crop loss are key factors when considering control strategies. The careful, regular monitoring of fields and the thorough examination of symptomatic plants are essential steps. The timing of control measures is also critical. Management of a destructive disease such as Phytophthora root rot may require early implementation of appropriate management measures. Besides being economically sound, a management strategy should also be simple, safe, inexpensive to apply, and sufficiently effective to reduce diseases to acceptable levels. Few management options possess all of these desirable qualities, however, so it usually is best to integrate multiple management options (e.g., planting resistant varieties, following beneficial cultural practices, and applying disease-control materials). 
Table. Important soilborne diseases and examples of management strategies*

\begin{tabular}{|c|c|c|c|c|}
\hline Crop & Disease & Pathogen & Symptoms and signs & Examples of management ${ }^{\dagger}$ \\
\hline \multicolumn{5}{|l|}{ Apiaceae } \\
\hline \multirow[t]{8}{*}{ Carrot } & $\begin{array}{l}\text { Bacterial } \\
\text { soft rot }\end{array}$ & $\begin{array}{l}\text { Erwinia carotovora, } \\
\text { E. chrysanthemi }\end{array}$ & $\begin{array}{l}\text { Soft, sunken, dull orange lesions } \\
\text { on taproots or rot of lower portions } \\
\text { of taproots. }\end{array}$ & $\begin{array}{l}\text { Plant in well-drained soil. } \\
\text { Avoid overwatering, especially } \\
\text { during warm weather. }\end{array}$ \\
\hline & Cavity spot & Pythium violae & $\begin{array}{l}\text { Small, elliptical, superficial } \\
\text { lesions on taproots. }\end{array}$ & $\begin{array}{l}\text { Apply fungicides. } \\
\text { Plant in well-drained soil. }\end{array}$ \\
\hline & Cottony rot & Sclerotinia sclerotiorum & $\begin{array}{l}\text { Soft, watery rot of stems and foliage. } \\
\text { Profuse white mycelium and } \\
\text { black sclerotia. }\end{array}$ & $\begin{array}{l}\text { Apply fungicides. } \\
\text { Provide ventilation down rows } \\
\text { by trimming foliage. } \\
\text { Deep plow to bury sclerotia. }\end{array}$ \\
\hline & Crown rot & Rhizoctonia solani & $\begin{array}{l}\text { Dark brown sunken lesions } \\
\text { near crowns. }\end{array}$ & $\begin{array}{l}\text { Avoid planting into fields with } \\
\text { undecomposed crop residue. }\end{array}$ \\
\hline & $\begin{array}{l}\text { Phytophthora } \\
\text { root rot }\end{array}$ & Phytophthora species & $\begin{array}{l}\text { Aboveground stunting, wilting, death. } \\
\text { Darkened, rotted roots. }\end{array}$ & $\begin{array}{l}\text { Avoid overwatering. } \\
\text { Plant in well-drained soil. }\end{array}$ \\
\hline & Root dieback & Pythium species & Forking and stubbing of taproots. & $\begin{array}{l}\text { Plant in well-drained soil. } \\
\text { Use pre-plant fungicides. }\end{array}$ \\
\hline & $\begin{array}{l}\text { Root knot } \\
\text { nematode }\end{array}$ & Meloidogyne species & $\begin{array}{l}\text { Aboveground stunting and yellowing. } \\
\text { Galls on deformed, stunted roots. }\end{array}$ & $\begin{array}{l}\text { Rotate with small grains. } \\
\text { Plant early in desert regions. }\end{array}$ \\
\hline & $\begin{array}{l}\text { Southern } \\
\text { blight }\end{array}$ & Sclerotium rolfsii & $\begin{array}{l}\text { Soft, brown rot of taproots with } \\
\text { white stringy mycelium and } \\
\text { brown sclerotia the size of } \\
\text { mustard seeds. }\end{array}$ & $\begin{array}{l}\text { Deep plow to bury sclerotia. } \\
\text { Rotate with grain crops. }\end{array}$ \\
\hline \multirow[t]{3}{*}{ Celery } & Crater spot & Rhizoctonia solani & $\begin{array}{l}\text { Brown-red, sunken lesions } \\
\text { on lower petioles. }\end{array}$ & $\begin{array}{l}\text { Avoid planting into fields with } \\
\text { undecomposed crop residue. } \\
\text { Avoid moving soil onto crowns } \\
\text { during cultivation. } \\
\text { Put transplants at proper depth. } \\
\text { Apply fungicides. }\end{array}$ \\
\hline & $\begin{array}{l}\text { Fusarium } \\
\text { yellows }\end{array}$ & $\begin{array}{l}\text { Fusarium oxysporum } \\
\quad \text { f. sp. apii }\end{array}$ & $\begin{array}{l}\text { Plant stunting, yellowing of foliage. } \\
\text { Brown discoloration of vascular } \\
\text { tissue. }\end{array}$ & $\begin{array}{l}\text { Use resistant cultivars. Select } \\
\text { fields without a history of } \\
\text { the disease. }\end{array}$ \\
\hline & Pink rot & Sclerotinia sclerotiorum & $\begin{array}{l}\text { Soft, watery, pink to brown rot } \\
\text { on lower stems. Profuse white } \\
\text { mycelium and black sclerotia. }\end{array}$ & $\begin{array}{l}\text { Apply fungicides. } \\
\text { Use drip irrigation. }\end{array}$ \\
\hline \multicolumn{5}{|l|}{ Asteraceae } \\
\hline \multirow[t]{2}{*}{ Lettuce } & Anthracnose & $\begin{array}{l}\text { Microdochium } \\
\text { panattonianum }\end{array}$ & $\begin{array}{l}\text { Tan leaf spots and lesions on leaves. } \\
\text { Spots are irregular and angular } \\
\text { in shape. White-pink spores } \\
\text { develop in the spot centers. } \\
\text { Disease is initiated from soilborne } \\
\text { inoculum, but later spreads via } \\
\text { airborne spores. }\end{array}$ & $\begin{array}{l}\text { Apply fungicides. } \\
\text { Select fields without a } \\
\text { history of the disease. }\end{array}$ \\
\hline & Big vein & M irafiori lettuce virus & $\begin{array}{l}\text { Distorted, enlarged leaf veins that } \\
\text { are abnormally cleared. Leaf and } \\
\text { head formation can likewise be } \\
\text { distorted. }\end{array}$ & $\begin{array}{l}\text { Disease is typically more severe } \\
\text { in the spring, so avoid infested } \\
\text { fields until later in the summer. } \\
\text { Use resistant cultivars. }\end{array}$ \\
\hline
\end{tabular}


Table. Continued

\begin{tabular}{|c|c|c|c|c|}
\hline Crop & Disease & Pathogen & Symptoms and signs & Examples of management ${ }^{\dagger}$ \\
\hline & Bottom rot & Rhizoctonia solani & $\begin{array}{l}\text { Petioles and leaves in contact with } \\
\text { soil develop irregular, brown, sunken } \\
\text { lesions. Lesions later break down } \\
\text { and decay, with the rot moving up } \\
\text { into the plant. }\end{array}$ & $\begin{array}{l}\text { Avoid planting in fields that have } \\
\text { undecomposed crop residues. }\end{array}$ \\
\hline & Corky root & $\begin{array}{l}\text { Rhizomonas } \\
\text { suberifaciens }\end{array}$ & $\begin{array}{l}\text { Yellow patches on main tap roots. } \\
\text { Patches later turn brown-green } \\
\text { and rough and corky. Plants may } \\
\text { be stunted. }\end{array}$ & $\begin{array}{l}\text { Use resistant cultivars. } \\
\text { Avoid using excess nitrogen. } \\
\text { Transplant the lettuce instead } \\
\text { of direct-seeding. } \\
\text { Plant lettuce in the spring. }\end{array}$ \\
\hline & Fusarium wilt & $\begin{array}{l}\text { F. oxysporum } \\
\text { f. sp. lactucum }\end{array}$ & $\begin{array}{l}\text { Aboveground stunting, collapse. } \\
\text { Brown discoloration of vascular tissue. }\end{array}$ & $\begin{array}{l}\text { Select fields without a history of } \\
\text { the disease. }\end{array}$ \\
\hline & Lettuce dieback & $\begin{array}{l}\text { Lettuce necrotic } \\
\text { stunt virus }\end{array}$ & $\begin{array}{l}\text { Lower leaves of Romaine cultivars } \\
\text { turn bright yellow, sometimes with } \\
\text { brown necrotic spots. The newer, } \\
\text { inner leaves are noticeably green } \\
\text { and thick. Plants can be severely } \\
\text { stunted. }\end{array}$ & $\begin{array}{l}\text { The pathogen is an unusual virus } \\
\text { that has no known vector. The } \\
\text { virus is spread in water and soil. } \\
\text { Plant Romaine in fields without } \\
\text { a history of the disease. }\end{array}$ \\
\hline & Lettuce drop & Sclerotinia minor & $\begin{array}{l}\text { Aboveground stunting, collapse. } \\
\text { Soft and rotted crowns. Profuse } \\
\text { white mycelium and small (1/8 inch) } \\
\text { black sclerotia form on crowns. }\end{array}$ & $\begin{array}{l}\text { Apply fungicides at thinning. } \\
\text { Select fields without a history of } \\
\text { the disease. } \\
\text { Deep plow to bury sclerotia. }\end{array}$ \\
\hline & Lettuce drop & $\begin{array}{l}\text { Sclerotinia } \\
\text { sclerotiorum }\end{array}$ & $\begin{array}{l}\text { Aboveground stunting, collapse. } \\
\text { Soft and rotted crowns. Profuse } \\
\text { white mycelium and large } \\
\text { (1/4 inch or larger) black sclerotia } \\
\text { form on crowns. Airborne ascospores } \\
\text { also cause leaf infections. }\end{array}$ & Apply fungicides at rosette stage. \\
\hline & Verticillium wilt & V. dahliae & $\begin{array}{l}\text { Aboveground stunting, collapse. } \\
\text { Black discoloration of vascular tissue. }\end{array}$ & $\begin{array}{l}\text { Select fields without a history of } \\
\text { the disease. }\end{array}$ \\
\hline \multirow[t]{6}{*}{ Brassicaceae } & & & & \\
\hline & Bottom rot & Rhizoctonia solani & $\begin{array}{l}\text { Dark, discolored lesions on leaves } \\
\text { touching soil. Only occurs on brassicas } \\
\text { that form heads. }\end{array}$ & Keep bed tops dry. \\
\hline & Clubroot & $\begin{array}{l}\text { Plasmodiophora } \\
\text { brassicae }\end{array}$ & $\begin{array}{l}\text { Aboveground stunting, death. Roots } \\
\text { are severely swollen and deformed. } \\
\text { Symptomatic roots often rot. }\end{array}$ & $\begin{array}{l}\text { Do not plant brassicas. } \\
\text { Apply lime for a soil pH >7.3. }\end{array}$ \\
\hline & $\begin{array}{l}\text { Cyst } \\
\text { nematode }\end{array}$ & Heterodera species & $\begin{array}{l}\text { Uneven growth and maturity of plants. } \\
\text { Tiny white to brown cysts on roots. }\end{array}$ & Rotate crops. \\
\hline & $\begin{array}{l}\text { Fusarium } \\
\text { yellows }\end{array}$ & $\begin{array}{l}\text { Fusarium oxysporum } \\
\text { f. sp. conglutinans }\end{array}$ & $\begin{array}{l}\text { Aboveground stunting, wilting, death. } \\
\text { Brown discoloration of vascular tissue. } \\
\text { Occurs primarily on cabbage. }\end{array}$ & Use resistant cultivars. \\
\hline & $\begin{array}{l}\text { Phytophthora } \\
\text { root rot }\end{array}$ & $\begin{array}{l}\text { Phytophthora } \\
\text { megasperma }\end{array}$ & $\begin{array}{l}\text { Aboveground stunting, wilting, death. } \\
\text { Darkened, rotted roots. }\end{array}$ & $\begin{array}{l}\text { Avoid overwatering. } \\
\text { Plant in well-drained soil. }\end{array}$ \\
\hline
\end{tabular}


Table. Continued

\begin{tabular}{llll}
\hline Crop & Disease & Pathogen & Symptoms and signs \\
\hline Verticillium wilt & Verticillium dahliae & $\begin{array}{l}\text { Aboveground stunting, wilting, death. } \\
\text { Black discoloration of vascular tissue }\end{array}$ \\
White mold & $\begin{array}{c}\text { Sclerotinia } \\
\text { sclerotionm, } \\
\text { Sclerotinia minor }\end{array}$ & $\begin{array}{l}\text { Soft, watery rot on stems in contact } \\
\text { with soil. Decay also occurs on } \\
\text { aboveground foliage. Profuse white } \\
\text { mycelium and black sclerotia. }\end{array}$
\end{tabular}

White rust Albugo candida

White blister-like pustules on leaves. Inoculum for this foliar disease comes from oospores in soil.

Wirestem Rhizoctonia solani Stunting, wilting, death of transplants. Hypocotyls are discolored, decayed, rotted. Brown mycelium present on decayed areas.

Examples of management ${ }^{\dagger}$

Use resistant cultivars.

Plant susceptible cultivars in winter.

Deep-plow prior to planting so sclerotia are buried.

Do not plant susceptible brassicas. Apply fungicides.

Avoid deep placement of transplants.

Keep bed tops dry.

Avoid planting into fields with undecomposed crop residue.

\section{Chenopodiaceae}

Spinach Damping-off

\section{Cucurbitaceae \\ Cucumber, \\ Melons, \\ Squash}

\section{Fusarium oxysporum, Pythium species, Rhizoctonia solani}
Macrophomina phaseolina

Damping-off

Fusarium wilt

\section{Pythium species, Rhizoctonia solani}

F. oxysporum f. sp. melonis (musk melon),

F. oxysporum f. sp. niveum (watermelon), F. oxysporum f. sp. cucumerinum (cucumber)

$\begin{array}{cc}\begin{array}{c}\text { Melon vine } \\ \text { decline }\end{array} & \begin{array}{c}\text { Monosporascus } \\ \text { cannonballus }\end{array} \\ \begin{array}{c}\text { Root knot } \\ \text { nematode }\end{array} & \text { Meloidogyne species } \\ \text { Sudden wilt } & \begin{array}{c}\text { Pythium } \\ \text { aphanidermatum }\end{array}\end{array}$

\section{Fabaceae Bean}

Pea

$$
\begin{aligned}
& \text { Ashy stem } \\
& \text { blight }
\end{aligned}
$$

Damping-off

\section{Macrophomina phaseolina}

Pythium species, Rhizoctonia solani
Poor stands. Wilting and death of emerged seedlings. Discolored, rotted roots and crowns.

Water-soaked green stem lesions that later turn tan. Profuse gumming on stems. Small, black structures (pycnidia) in lesions.

Water-soaked lesions on roots and stems. Wilting, death.

Dark brown lesions on one side of stems. Brown discoloration of vascular tissue.

Vines collapse. Black, round structures (perithecia) on dead roots.

Aboveground stunting and yellowing. Galls on deformed, stunted roots.

Vines collapse. Water-soaked beige to orange lesions on roots.

Black sunken lesions on stems near soil line.

Water-soaked lesions on roots and stems. Wilting, death.
Plant in well-drained soil. Avoid overwatering. Apply fungicides for Pythium.

Avoid stressing plants. Rotate with grains.

Avoid overwatering.

Use resistant cultivars.
Avoid planting in infested fields. Avoid overwatering and stressing of plants.

Preplant chemical treatment, postplant treatment with oxamyl.

Avoid overwatering.

Avoid stressing plants.

Avoid overwatering. 
Table. Continued

\begin{tabular}{|c|c|c|c|c|}
\hline Crop & Disease & Pathogen & Symptoms and signs & Examples of management ${ }^{\dagger}$ \\
\hline & $\begin{array}{l}\text { Fusarium root } \\
\text { rot }\end{array}$ & $\begin{array}{l}\text { Fusarium solani f. sp. } \\
\text { phaseoli }\end{array}$ & Brown-red lesions on hypocotyls. & Use tolerant cultivars. \\
\hline & $\begin{array}{l}\text { Root knot } \\
\text { nematode }\end{array}$ & Meloidogyne species & $\begin{array}{l}\text { Aboveground stunting and yellowing. } \\
\text { Galls on deformed, stunted roots. }\end{array}$ & $\begin{array}{l}\text { Rotate with small grains. } \\
\text { Use resistant cultivars. }\end{array}$ \\
\hline \multicolumn{5}{|l|}{ Liliaceae } \\
\hline \multirow[t]{5}{*}{ Alliums } & Damping-off & $\begin{array}{l}\text { Pythium species, } \\
\text { Rhizoctonia species }\end{array}$ & $\begin{array}{l}\text { Poor stands. Wilting and death of } \\
\text { emerged seedlings. Discolored, } \\
\text { rotted roots and crowns. }\end{array}$ & $\begin{array}{l}\text { Plant in well-drained soil. } \\
\text { Avoid overwatering. } \\
\text { Apply fungicides for Pythium. }\end{array}$ \\
\hline & $\begin{array}{l}\text { Fusarium } \\
\text { basal rot }\end{array}$ & $\begin{array}{l}\text { Fusarium oxysporum } \\
\text { f. sp. cepae }\end{array}$ & $\begin{array}{l}\text { Chlorosis and dieback of foliage. } \\
\text { Brown discoloration of bulbs. } \\
\text { Rotted roots and basal plates. }\end{array}$ & $\begin{array}{l}\text { Use a 4-year crop rotation. } \\
\text { Use resistant cultivars. }\end{array}$ \\
\hline & Pink root & Phoma terrestris & $\begin{array}{l}\text { Roots turn pink, then purple. Roots } \\
\text { wither and eventually die. Bulbs } \\
\text { are stunted. }\end{array}$ & $\begin{array}{l}\text { Use a 3- to } 6 \text {-year crop rotation. } \\
\text { Use resistant cultivars. } \\
\text { Solarize the soil. }\end{array}$ \\
\hline & $\begin{array}{l}\text { Stem } \& \text { bulb } \\
\text { nematode }\end{array}$ & Ditylenchus dipsaci & $\begin{array}{l}\text { Tan discoloration and rot of stems, } \\
\text { bulbs, and basal plates. Aboveground } \\
\text { stunting, collapse of plant. }\end{array}$ & $\begin{array}{l}\text { Use non-infested or disinfested } \\
\text { sets and seed. }\end{array}$ \\
\hline & White rot & Sclerotium cepivorum & $\begin{array}{l}\text { Yellowing and eventual death of } \\
\text { foliage. Decayed roots. Stunted } \\
\text { and dead plants. White mycelium } \\
\text { and black sclerotia on infected bulbs. }\end{array}$ & $\begin{array}{l}\text { Use sanitation. } \\
\text { Use pathogen-free garlic "seed." } \\
\text { Soil fumigation, solarization, and } \\
\text { fungicides provide partial control. } \\
\text { Select fields without a history of } \\
\text { the disease. }\end{array}$ \\
\hline \multirow[t]{2}{*}{ Asparagus } & Fusarium wilt & $\begin{array}{l}\text { Fusarium oxysporum } \\
\text { f. sp. asparagi }\end{array}$ & $\begin{array}{l}\text { Yellowing of foliage, stunted plants. } \\
\text { Brown discoloration of vascular tissue. }\end{array}$ & $\begin{array}{l}\text { Use sanitation. } \\
\text { Use pathogen-free transplants. }\end{array}$ \\
\hline & $\begin{array}{l}\text { Phytophthora } \\
\text { crown and } \\
\text { spear rot }\end{array}$ & Phytophthora species & $\begin{array}{l}\text { Soft brown lesions above and below } \\
\text { the soil line. Affected areas on shoots } \\
\text { are flattened. }\end{array}$ & $\begin{array}{l}\text { Avoid overwatering. } \\
\text { Plant in well-drained soil. }\end{array}$ \\
\hline \multicolumn{5}{|l|}{ Solanaceae } \\
\hline \multirow[t]{3}{*}{ Pepper } & Damping-off & $\begin{array}{l}\text { Phytophthora species, } \\
\text { Pythium species, } \\
\text { Rhizoctonia solani }\end{array}$ & $\begin{array}{l}\text { Poor stands. Wilting and death of } \\
\text { emerged seedlings. Discolored, } \\
\text { rotted roots and crowns. }\end{array}$ & $\begin{array}{l}\text { Plant in well-drained soil. } \\
\text { Avoid overwatering. } \\
\text { Apply fungicides for Pythium. }\end{array}$ \\
\hline & $\begin{array}{l}\text { Phytophthora } \\
\text { root rot }\end{array}$ & Phytophthora capsici & $\begin{array}{l}\text { Aboveground stunting, wilting, } \\
\text { and death. Darkened, rotted roots. }\end{array}$ & $\begin{array}{l}\text { Avoid overwatering. } \\
\text { Plant in well-drained soil. }\end{array}$ \\
\hline & Verticillium wilt & Verticillium dahliae & $\begin{array}{l}\text { Aboveground stunting, wilting, } \\
\text { and death. }\end{array}$ & $\begin{array}{l}\text { Use a 3-year crop rotation. } \\
\text { Brown discoloration of vascular } \\
\text { tissue. }\end{array}$ \\
\hline \multirow[t]{2}{*}{ Potato } & Black dot & $\begin{array}{l}\text { Colletotrichum } \\
\text { atramentarium }\end{array}$ & $\begin{array}{l}\text { Rotting of below ground stems } \\
\text { and stolons. Black dot-like sclerotia } \\
\text { visible in lesions. }\end{array}$ & Use pathogen-free "seed." \\
\hline & Charcoal rot & Macrophomina phaseoli & $\begin{array}{l}\text { Stem lesions that result in } \\
\text { aboveground wilting and yellowing. }\end{array}$ & $\begin{array}{l}\text { Avoid dry soils. } \\
\text { Use pathogen-free "seed." }\end{array}$ \\
\hline
\end{tabular}


Table. Continued

\begin{tabular}{|c|c|c|c|c|}
\hline Crop & Disease & Pathogen & Symptoms and signs & Examples of management ${ }^{\dagger}$ \\
\hline & $\begin{array}{l}\text { Fusarium } \\
\text { dry rot }\end{array}$ & Fusarium sambucinum & $\begin{array}{l}\text { Extensive, dry, brown internal decay } \\
\text { of tubers. }\end{array}$ & $\begin{array}{l}\text { Avoid wounding tubers. } \\
\text { Apply fungicides to seed tubers. }\end{array}$ \\
\hline & Leak & Pythium species & $\begin{array}{l}\text { Water-soaked areas in tubers that } \\
\text { are separated from healthy tissue } \\
\text { by a dark boundary line. Affected } \\
\text { tissue turns brown to black with } \\
\text { exposure to air. In severe cases, } \\
\text { only the skin of the tuber remains. }\end{array}$ & $\begin{array}{l}\text { Avoid wounding tubers. } \\
\text { Let skins mature before harvest. }\end{array}$ \\
\hline & Pink rot & $\begin{array}{l}\text { Phytophthora } \\
\text { erythroseptica }\end{array}$ & $\begin{array}{l}\text { Cream-colored decay of tubers that } \\
\text { turns pink on exposure to air. } \\
\text { Affected areas in tubers are } \\
\text { delimited by dark lines. }\end{array}$ & $\begin{array}{l}\text { Plant in well-drained soil. } \\
\text { Avoid overwatering, especially } \\
\text { late in the season. }\end{array}$ \\
\hline & Pow dery scab & $\begin{array}{l}\text { Spongospora } \\
\text { subterranean }\end{array}$ & $\begin{array}{l}\text { Purple-brown pustules that darken } \\
\text { with masses of dark brown spore } \\
\text { balls. }\end{array}$ & $\begin{array}{l}\text { Use a } 3 \text { to } 10 \text { year crop rotation. } \\
\text { Use pathogen-free "seed." } \\
\text { Plant in well-drained soil. }\end{array}$ \\
\hline & $\begin{array}{l}\text { Rhizoctonia } \\
\text { canker } \\
\text { (Black scurf) }\end{array}$ & Rhizoctonia solani & $\begin{array}{l}\text { Red-brown stem lesions. Yellowing } \\
\text { of foliage if lesions girdle stems. } \\
\text { Aerial tubers. Leafrolling. }\end{array}$ & $\begin{array}{l}\text { Use pathogen-free "seed." } \\
\text { Apply fungicide "seed" treatments. } \\
\text { Black sclerotia on tuber surfaces. }\end{array}$ \\
\hline & $\begin{array}{l}\text { Root knot } \\
\text { nematode }\end{array}$ & Meloidogyne species & $\begin{array}{l}\text { Aboveground stunting and yellowing. } \\
\text { Galls on deformed, stunted roots. }\end{array}$ & Rotate with small grains. \\
\hline & Silver scurf & $\begin{array}{l}\text { Helminthosporium } \\
\text { solani }\end{array}$ & $\begin{array}{l}\text { Light brown circular spots with } \\
\text { indistinct margins. Affected areas } \\
\text { have a silvery sheen. }\end{array}$ & $\begin{array}{l}\text { Use pathogen-free "seed." } \\
\text { Apply fungicide "seed" treatments. }\end{array}$ \\
\hline & Verticillium wilt & Verticillium dahliae & $\begin{array}{l}\text { Aboveground stunting, wilting, } \\
\text { and death. Brown discoloration of } \\
\text { vascular tissue. }\end{array}$ & Use pathogen-free "seed." \\
\hline & White mold & Sclerotinia sclerotiorum & $\begin{array}{l}\text { Soft, watery rot on stems. } \\
\text { Profuse white mycelium and } \\
\text { black sclerotia. }\end{array}$ & $\begin{array}{l}\text { Avoid using excessively high rates } \\
\text { of nitrogen fertilizers. } \\
\text { M inimize wetting of foliage. }\end{array}$ \\
\hline \multirow[t]{5}{*}{ Tomato } & Damping-off & $\begin{array}{l}\text { Phytophthora species, } \\
\text { Pythium species, } \\
\text { Rhizoctonia solani }\end{array}$ & $\begin{array}{l}\text { Poor stands. Wilting and death } \\
\text { of emerged seedlings. Discolored, } \\
\text { rotted roots and crowns. }\end{array}$ & $\begin{array}{l}\text { Plant in well-drained soil. } \\
\text { Avoid overwatering. }\end{array}$ \\
\hline & $\begin{array}{l}\text { Fusarium } \\
\text { foot rot }\end{array}$ & Fusarium solani & $\begin{array}{l}\text { Brown lesions on tap or major } \\
\text { lateral roots. Chlorosis and necrosis } \\
\text { of leaves. }\end{array}$ & $\begin{array}{l}\text { Use sanitation to avoid } \\
\text { moving the pathogen. }\end{array}$ \\
\hline & Fusarium wilt & $\begin{array}{l}\text { Fusarium oxysporum } \\
\text { f. sp. lycopersici }\end{array}$ & $\begin{array}{l}\text { Aboveground stunting, wilting, and } \\
\text { flagging of individual branches. } \\
\text { Brown discoloration of vascular } \\
\text { tissue. }\end{array}$ & Use resistant cultivars. \\
\hline & $\begin{array}{l}\text { Phytophthora } \\
\text { root rot }\end{array}$ & Phytophthora species & $\begin{array}{l}\text { Aboveground stunting, wilting, and } \\
\text { death. Darkened, rotted roots. }\end{array}$ & $\begin{array}{l}\text { Avoid overwatering. } \\
\text { Plant in well-drained soil. }\end{array}$ \\
\hline & $\begin{array}{l}\text { Root knot } \\
\text { nematode }\end{array}$ & Meloidogyne species & $\begin{array}{l}\text { Aboveground stunting and yellowing. } \\
\text { Galls on deformed, stunted roots. }\end{array}$ & Rotate with small grains. \\
\hline
\end{tabular}


Table. Continued

\begin{tabular}{lllll}
\hline Crop & Disease & Pathogen & Symptoms and signs & Examples of management $^{\mathbf{\dagger}}$ \\
\hline Verticillium wilt & Verticillium dahliae & $\begin{array}{l}\text { Aboveground stunting and wilting. } \\
\text { Brown discoloration of vascular } \\
\text { tissue. }\end{array}$ & Use resistant cultivars. \\
White mold & Sclerotinia sclerotiorum & $\begin{array}{l}\text { Soft, watery rot on stems. Profuse } \\
\text { white mycelium and black sclerotia } \\
\text { on bleached areas of affected stems. }\end{array}$ & - \\
\hline
\end{tabular}

* For more complete information on these and other soilborne diseases and for more details on disease management options, refer to the Pest Management Guidelines found on the UC Statewide IPM Program web site (http://www.ipm.ucdavis.edu).

$\dagger$ General control measures that apply to almost all soilborne diseases, such as soil fumigation and crop rotations, are not listed for every entry.

\section{DISEASE-CONTROL OPTIONS}

Host resistance. Disease-resistant plants are an obvious and effective control measure because resistance to many pathogens can be both complete and long lasting. A plant can express resistance through the action of a single gene that confers immunity (resistance to certain races of Fusarium wilt, for example) or through multiple genes that result in a broad resistance to many pathogens. Single-gene resistance, called vertical resistance, limits both the initial level of infection and the production of inoculum. This sort of resistance can be overcome, however, by new strains of the target pathogen. Multiple-gene resistance, called horizontal resistance, allows some disease to develop but limits it to a tolerable level. Use resistant cultivars whenever they are available.

Cultural controls. There are three areas of focus for cultural control: helping plants avoid contact with pathogens, reducing inoculum in the host plant's environment, and creating environmental conditions that are unfavorable to disease development. Cultural controls that reduce host-pathogen contact include the use of fields that have no history of the soilborne disease of concern, the inhibition of pathogen spread from infested soil to uninfested fields, the use of seeds that do not harbor pathogens above acceptable established thresholds or the use of disease-free seeds and transplants, and the planting of seeds and transplants to proper depths.

Cultural methods that reduce inoculum levels in the environment include crop rotation, proper irrigation, good sanitation, and soil solarization. Certain cover crops (mustard species) and brassica crops (such as broccoli) can also help reduce soilborne pathogen populations; when incorporated into the soil, residues from these plants release chemicals that either directly inhibit pathogens or enhance soil microflora populations that subsequently compete with pathogens. To create conditions unfavorable for disease development, a grower can use optimum plant spacing to reduce relative humidity around plants, provide good soil drainage through proper soil preparation and irrigation practices, use mulches to physically isolate aboveground plant parts from contact with the soil, and fertilize the crop properly to prevent stressed or overly succulent plants. A good example of a specific cultural practice is the nowwidespread use of drip irrigation in vegetable crops. Drip irrigation usually allows for a more precise delivery of water, resulting in better water management, reduced soil saturation, and a lowered risk of soilborne diseases such as root rots. 
Disease-control chemicals. Agricultural chemicals and other disease-control materials are options that you can sometimes integrate into a strategy to manage soilborne pathogens. Pre-plant fumigants (e.g., methyl bromide, chloropicrin, or metham sodium) are often highly successful in reducing soilborne inoculum, though their use is expensive and strictly regulated. Fungicide-treated seed is an important tool against certain seed and seedling diseases. In some situations, a fungicide applied to the soil or to plants can be an effective disease management tool. For example, the application of fungicides to spinach seed lines at planting can effectively prevent damping-off caused by Pythium. One way to control lettuce drop caused by Sclerotinia minor is to apply fungicides to plants at the thinning stage. For most soilborne pathogens, however, field-applied fungicides usually are not very effective.

Classical biological controls are also under development. In this approach, a product containing a viable antagonistic organism is applied to combat the target pathogen. This type of treatment is under development, but is not yet available or effective for most soilborne diseases of vegetables. 


\section{FOR MORE INFORMATION}

You'll find detailed information on many aspects of vegetable production and plant diseases in these titles and in other publications, slide sets, videos, and CD-ROMs from UC ANR:

Commercial G reenhouse Vegetable Handbook, publication 21575 Growing Field Crops: Vegetables, M elons, and M ore, CD-ROM 3413

UC IPM Pest Management Guidelines, various publication numbers for individual crops

To order these products, visit our online catalog at http://anrcatal og.ucdavis.edu. You can also place orders by mail, phone, or FAX, or request a printed catalog of publications, slide sets, videos, and CD-ROM s from

University of California

Agriculture and Natural Resources

Communication Services

6701 San Pablo Avenue, 2nd Floor

Oakland, California 94608-1239

Telephone: (800) 994-8849 or (510) 642-2431, FAX: (510) 643-5470 e-mail inquiries: danrcs@ucdavis.edu

An electronic version of this publication is available on the ANR Communication Services Web site at http://anrcatalog.ucdavis.edu.

Publication 8099

(c) 2003 by the Regents of the University of California, Division of Agriculture and Natural Resources. All rights reserved.

The University of California prohibits discrimination against or harassment of any person employed by or seeking employment with the University on the basis of race, color, national origin, religion, sex, physical or mental disability, medical condition (cancer-related or genetic characteristics), ancestry, marital status, age, sexual orientation, citizenship, or status as a covered veteran (special disabled veteran, Vietnam-era veteran or any other veteran who served on active duty during a war or in a campaign or expedition for which a campaign badge has been authorized).

University Policy is intended to be consistent with the provisions of applicable State and Federal laws.

Inquiries regarding the University's nondiscrimination policies may be directed to the Affirmative Action/Staff Personnel Services Director, University of California, Agriculture and Natural Resources, 300 Lakeside Drive, 6th Floor, Oakland, CA 94612-3550 (510) 987-0096. For information about obtaining this publication, call (800) 994-8849. For downloading information, call (530) 754-5112.

pr-11/03-WJCNFG

ISBN 978-1-60107-273-3

This publication has been anonymously peer reviewed for technical accuracy by University of California scientists and other qualified professionals. The review process was managed by the ANR Associate Editor for Pest Management. 